\title{
INCOME SITUATION OF FARMER FAMILIES IN POLAND IN THE LIGHT OF ECONOMIC TRANSFORMATIONS AND EUROPEAN INTEGRATION
}

\section{Barbara Chmielewska}

\begin{abstract}
Political and economic transformations in Poland, which began in the 1990s, had a significant impact on the economic situation of all households, and in particular on farmers' households. These households experienced the highest, among other social and professional groups, real decrease of income. Also price relations in agriculture deteriorated. Agricultural production became less profitable, mostly as a result of the increase of prices of materials used for the production.

The supply of agricultural raw materials was higher than the demand, therefore farmers encountered problems with selling their products. The income structure experienced a decrease in the share of income from individual farm, while the gainful employment outside of agriculture and social benefits grew. Polish integration with the EU and including Polish agriculture in the common agricultural policy contributed to the amelioration of the farms' economic situation, mainly as a result of influx of funds under direct payments.

The level of the support depended on the size of a farm, thus small farms, most numerous in Poland, did not benefit significantly. A considerable range of poverty in rural areas and a disparity between the income and expenditures of households, to the disadvantage of farming families, still prevails.
\end{abstract}

Keywords: farmers' households, income, expenditure, income shaping factors, direct payments 